\title{
The use of local energy resources for remote populated areas
}

\author{
Victor Bochkarev ${ }^{1}$, Elena Gubiy ${ }^{2}$, Nina Dekanova ${ }^{1}$, Valery Zorkaltsev ${ }^{2}$, and Veniamin \\ Khan $^{1, *}$ \\ ${ }^{1}$ Irkutsk National Research Technical University, 664074, Lermontova str., 83, Irkutsk, Russia \\ ${ }^{2}$ L. A. Melentiev Institute of Energy Systems of the Siberian Branch of the Russian Academy of \\ Sciences, 664033, Lermontova str., 130, Irkutsk, Russia
}

\begin{abstract}
The economic and environmental benefits of using local energy resources for the heat supply of remote settlements are discussed. Particular attention is paid to the problem of energy supply of the Baikal tourist and recreational zone, in which environmental restrictions have a significant influence on decision-making. The results of the research of the energy plantations functioning for the fuel supply of remote settlements on the basis of application the economic-mathematical model for their analysis and optimization are presented in the paper. The problem of choosing the optimal combination of energy plantations, and imported and local fuel is discussed. The influence of the volume of the fuel demand, the prices of the long-range fuel, the transport factor on the economic efficiency depending on the configuration and the required area of the energy plantation is considered. The options to increase the efficiency of heat supply for small and medium-sized settlements in the Baikal region are analyzed.
\end{abstract}

Low efficiency of heat supply systems is one of the most serious problems hampering the development of the East Siberian region. This is especially true for remote settlements $[1,2]$. One of the central problems of the functioning and development of the Baikal nature territory, namely its energy supply, is considered in the paper. Until recently, relatively cheap electricity and firewood delivered by the forestry and local population have been the main sources of the energy supply. In large settlements and cities where special boiler houses function, they use an imported coal. In the most remote areas (Peschanaya Bay and Khakusy), diesel fuel is used.

In the Irkutsk energy system, the low cost of electricity generated at HPPs offset the unprofitable operation of CHP and ensured the maintenance of low electricity tariffs, which for the rural population were about three times lower than in the neighboring regions. In view of the forthcoming reforms, in the coming years we should expect a significant (three or more times) increase in electricity fees in many settlements of the Irkutsk region. This will make inefficient the use of electricity for heating in large scales.

The wide use of the imported fuel (coal, diesel fuel, and fuel oil) in the populated areas, camp sites and cottages in the areas adjacent to Baikal is not only expensive due to transportation over long distances, but also inappropriate for environmental restrictions. Lake

* Corresponding author: khan@istu.edu 
Baikal is a place of the World Natural Heritage of UNESCO, where prohibitive measures are actively applied to activities that damage the environment.

The situation for heat-consuming objects from small and medium-sized boiler houses is particularly difficult. The features of the heat supply of such objects are most clearly manifested in small and medium-sized settlements. The level of tariffs ranges from 1800 rubles / Gcal for the southern areas of the Irkutsk region to 3500 rubles / Gcal and above for northern and remote areas. The growth of tariffs is constrained by the efforts of regulatory bodies, but there are a number of objective factors affecting the level of economically sound prices. These include: the structure of fuel prices, logistics, economically justified levels of wages, payments for emissions, investment components and others. Ignoring these factors in the long term is impossible and inadvisable. The analysis of the dynamics of tariff formation shows that in many cases tariffs are unreasonably underestimated [3]. This practice, firstly, leads to the distorted estimates of the profitability and prospects of the selected activities, and secondly, leads to the degradation of the communal heat supply systems. The refuse from the artificial tariff restraint will inevitably entail their considerable growth.

Taking into account the above-mentioned factors, in many settlements, remote from the coal production and logistics centers, an economically justified tariff should now amount to about 2500 rubles / Gcal). In view of the dynamics of the main components of the tariff, we should expect further growth to 3500 rubles / Gcal in 2022 and up to 4000 rubles / Gcal in 2027. Such a rise in tariffs is fraught with serious crisis phenomena and the degradation of the region. To avoid such a scenario, fundamentally different approaches to the heat supply schemes are needed.

One of the key directions in reforming the heat power industry is "a transition to a free pricing system, including the liberalization of prices ... in the framework of the price of an "alternative boiler house" [2].

The options for the alternative approaches can be the following:

- Transition to the heat sources with cogeneration;

- Use of more economical fuels;

- Use of renewable and non-traditional sources of energy;

- Optimization of the heat supply scheme by transferring a part of the objects to work with autonomous heat sources.

Biofuel. The use of local biofuels (chips, pellets, solid household waste) can be one of the options for such alternative solutions [3]. This should take into account the specific conditions of operation and the characteristics of the objects. The cost of the fuel delivery is an important factor for facilities located in remote settlements. The Irkutsk region is a leader among the constituent entities of the Russian Federation in terms of the timber harvesting (about 20 million $\mathrm{m}^{3}$ per year). Therefore, the processes of processing and utilization of timber processing waste are topical.

When considering the use of biofuels, it should immediately be noted that virtually all types of biofuel have relatively low energy density, and its transporting for long distances significantly increases the cost. Below are considered the options for the use of the imported biofuels, and the options for using local biofuels. Subject to availability of local biofuel resources, the cost of producing thermal energy on the own biofuel is significantly lower than that of the imported biofuels. Therefore, it is advisable to consider only those biofuels that are available in sufficient quantities in the Baikal urban zone.

It should also be borne in mind that the use of local biofuels is beneficial not only from the energy point of view, but also from the environmental one, as waste is usually used as biofuel. The results of the analysis of variants of technical solutions as applied to the conditions of the city of Baikalsk are considered. This city is interesting because it concentrates the most typical problems of settlements of the Baikal region. This includes considerable physical and moral deterioration of the equipment of the existing CHP, which 
remained "inherited" from the now closed pulp and paper mill (BPPM); a high level of expenses for own needs, non-optimal composition of generating equipment, leading to overconsumption of fuel; a high level of deterioration of the thermal networks and, accordingly, loss of thermal energy both with the heat carrier, and through thermal insulation. By minimum estimates, the level of heat loss is at least $28 \%$ of the maximum load of $46.1 \mathrm{Gcal}$ $/ \mathrm{h}$. The situation is exacerbated by the absence of elevator units or other devices for converting the coolant parameters from the vast majority of the heat network subscribers; the lack of discipline in contractual relations; the lack of accounting; the misbalances of internal heating systems and coolant drains, caused by misalignment of heat networks. The choice of possible options for optimizing the heat supply scheme is limited by strict environmental restrictions, stipulated by the Order of the Ministry of Natural Resources of Russia on March 5, 2010 № 63 “On the approval of the maximum permissible impacts on the unique ecological system of Lake Baikal and the list of harmful substances, including substances belonging to the categories of especially dangerous, highly dangerous, moderately dangerous for the unique ecological system of Lake Baikal" and the Federal Law of May 1, 1999 No. 94-FZ "On the Protection of Lake Baikal" [4,5]. In particular, due to these normative acts, it is impossible to continue using relatively cheap fuel in the form of coal. The use of clean electric energy can lead to unacceptable tariffs for the population and business up to 5 thousand rubles / Gcal. Possible options for obtaining relatively affordable thermal energy based on the use of heat pump systems will be presented below.

In the zone of the city of Baikalsk, there are several types of biofuel in sufficient quantities. First of all, these are wood waste. The reserves of wood to be cut down are estimated at about 9.5 million $\mathrm{m}^{3}$. If one takes a share of waste as $40 \%$, then, in absolute terms, it will be 3.8 million $\mathrm{m}^{3}$. The lowest calorific value of wood waste at a humidity of up to $40 \%$ is estimated at $2.05 \mathrm{Gcal} /$ ton. The prospective annual consumption of the thermal energy is estimated at $350,000 \mathrm{Gcal} /$ year. If this volume of consumption is completely covered by the wood waste, the annual wood consumption will be 175,000 tons. With a density of the wood waste of $0.7 \mathrm{t} / \mathrm{m}^{3}$, this is approximately $285,000 \mathrm{~m}^{3}$ per year. With such volumes of consumption, available timber reserves are sufficient to cover the needs of Baikalsk for about 20 years. Taking into account the fact that this is a renewable resource, it can be considered that the potential of wood waste is sufficient for a long term. In addition, it should be kept in mind that an increasing part of the consumption of thermal energy will be covered by other sources of energy, including solid domestic waste, possibly, lignin; solar heat supply systems, etc.

In addition, solid household waste should be referred to bio-resources, the potential of which can be estimated as follows. The volume of garbage disposal is, according to the Baikalsk Administration data, about 3.5 thousand $\mathrm{m}^{3} /$ month, that is, 42 thousand $\mathrm{m}^{3} /$ year. To involve this potential in the turnover, it is necessary to organize separate collection of garbage and primary processing of solid waste. The organic part of garbage is $60 \%$, or 25 thousand $\mathrm{m}^{3} /$ year. With a bulk density of 0.5 ton $/ \mathrm{m}^{3}$ of solid waste, this amounts to approximately 12,000 tons per year. The use of the solid household waste has a dual effect environmental and energy. When using solid waste, the required volume of wood processing is reduced to 240 thousand $\mathrm{m}^{3}$ per year.

To some extent, the need for this type of fuel can be provided through the reasonable use of forest resources of the adjacent territories, including sanitary felling, undoubtedly, if they are accompanied by active forest plantations. But specially created energy plantations obviously should be the main source of firewood in the future. The areas, most attractive for tourism, the coast of the Small Sea (Olkhon Island and Priolkhonie, where the extensive Tazheran steppe is located), the area of the settlement of Goloustnoye, the territory that was considered for the construction of the so-called "Baikal City" and which possesses huge space are especially promising for the energy plantations. It should be noted that 
entrepreneurs are now actively demonstrating the awaken interest in creating energy plantations in the Baikal area. The use of wood as fuel can also be one of the directions for solving this acute problem of the heat supply in the city of Baikalsk. Special attention is planned to be delivered to this issue.

For effective use of bio-resources it is necessary to do the following:

- To create sawn timber production, in which waste from the timber processing gives practically free raw material for biofuel preparation;

- To create production facilities for the preparation of wood waste (grinding, drying and, if necessary, granulation).

- To create of a special fleet for fuel transportation;

- To organize warehouse storage, reception and delivery of fuel to the heat source;

- To create own energy source, taking into account high energy intensity of processing and drying of wood.

The use of efficient, environmentally friendly and safe biofuel makes it possible to bring heat sources closer to consumers. Thus, it is possible to partially decentralize the heat supply system, which, in turn, allows solving a number of thermal network problems. The calculation of the cost of thermal energy in relation to a mini-CHP is given in the Table 1 . The characteristics of the mini-CHP operating on dry chips are as follows: three steam boilers with a capacity of 25 tons of steam per hour and backpressure turbines of $6 \mathrm{MW}$, a heat output of $69 \mathrm{Gcal} / \mathrm{h}$ and an electric capacity of $9.74 \mathrm{MW}$. The calculation is made for the case when the price of electricity supply is 1.0 rubles $/ \mathrm{kWh}$. At a selling price of electricity of 2 rubles $/ \mathrm{kWh}$, the cost of production of thermal energy will be 0.698 rubles / Gcal.

Table 1. Calculation of the thermal energy cost for mini-CHP on wood chips.

\begin{tabular}{|c|c|c|}
\hline \multicolumn{1}{|c|}{ Indicator } & Value & Unit of measurement \\
\hline Annual heat production capacity & 258135 & thousand Gcal \\
\hline Annual capacity of electricity & 28403 & MWh \\
\hline $\begin{array}{l}\text { Total energy production, taking into account the } \\
\text { efficiency of 90\% }\end{array}$ & 286817 & Gcal. \\
\hline Costs: & & \\
\hline$-\quad$ fuel, t chips & 75478 & $\mathrm{t} /$ year \\
\hline$-\quad$ fuel, with the price of dry chips 800 rubles & 60382 & thousand rubles. \\
\hline$-\quad$ depreciation & 63318 & thousand rubles \\
\hline$-\quad$ Other & 113184 & thousand rubles \\
\hline$-\quad$ minus EE revenue at a price of 1 ruble / $\mathrm{kWh}$ & 28403 & thousand rubles \\
\hline Total & 208481 & thousand rubles \\
\hline The cost of heat & 0,808 & rubles / Gcal \\
\hline
\end{tabular}

Gas Turbine Mini-CHP. Another option is the gas-turbine Mini-CHP operating on a liquefied hydrocarbon-containing gas (LPG) [6]. The autonomous gas power plant includes the following: gas turbines; management and security systems; thermal equipment, such as heat recovery boilers for combustion products leaving the gas turbine; power cells; transformers; a building; backup fuel storage; peak boiler room; chimneys; cooling towers; circulating pumps; and backup generators and others units, necessary for the normal operation of the system. For calculating the delivery cost, it is necessary to take into account the cost of design, procurement, installation and commissioning. Single electric power of the gas-turbine Mini-CHP varies from 0.6 MW to 50 MW. The efficiency of production of the electric energy on gas turbine generators is $38.0-38.6 \%$. The temperature of the gases at the exit is more than $400^{\circ} \mathrm{C}$. The thermal power at the utilization of thermal energy of gases after the turbine is approximately up to 1.28 of the electric power. The efficiency of the thermal energy production is $49 \%$. The overall efficiency is $87.3 \%$. The options for using LPG for Mini-CHP with a steam turbine cycle are also considered. From the point of view of the heat 
supply, the steam turbine CHP plants have more favorable ratio between electric and thermal capacity. The Table 2 presents calculations of the cost of heat at the Mini-CHP operating on LPG at a price of LPG of 20 thousand rubles per ton, and at a price of electricity supply of $1.0 \mathrm{rub} / \mathrm{kWh}$.

Table 2. Calculation of the cost of thermal energy when LPG is used.

\begin{tabular}{|l|c|c|}
\hline \multicolumn{1}{|c|}{ Indicator } & Value & $\begin{array}{c}\text { Unit of } \\
\text { measurement }\end{array}$ \\
\hline Annual heat output & 416897 & thousand Gcal. \\
\hline Annual capacity of electricity & 82381 & MW h \\
\hline Total, including efficiency 92\% & 487745 & $\mathrm{Gcal}$ \\
\hline Costs: & 62319 & $\mathrm{t} /$ year \\
\hline$-\quad$ fuel, t LPG & 1246375 & thousand rubles \\
\hline$-\quad$ fuel, at the price of LPG 20 thousand rbl. / t & 145000 & thousand rubles \\
\hline$-\quad$ depreciation & 113184 & thousand rubles \\
\hline$-\quad$ Other & 82381 & thousand rubles \\
\hline $\begin{array}{l}\text { minus the income from the EE at a price of 1 ruble / } \\
\text { kWh }\end{array}$ & 1422 & thousand rubles \\
\hline Total & 3411 & rubles / Gcal \\
\hline The cost of heat &
\end{tabular}

At the cost of LPG 15 thousand rubles / ton, the cost of production of thermal energy will be 2644 rubles / Gcal. If we accept the price of electricity supply of 2.5 rubles per $\mathrm{kWh}$, the cost of heat production will be 2368 rubles per Gcal. Thus, when using a liquefied hydrocarbon-containing gas, a relatively reasonable cost of heat can be obtained by using cogeneration, at the cost of LPG not above 15 thousand rubles per ton and at a price of electric energy released 2.5 rubles / $\mathrm{kWh}$.

Oddly enough, one of the obstacles for the use of energy plantations to provide fuel for the tourist and recreational zone is the environmental legislation that restricts production activities in the Baikal nature area. Organizational and legal aspects of activities at Baikal are also inadequate: it was easier to introduce bans than to think over a rational system for managing the development of the Baikal region.

Heat pumps are effective and increasingly popular means of reducing cost of heat production [6.7]. Heat pumps convert low-potential thermal energy into a medium-potential one. The temperature of the coolant at the outlet from the heat pump can be from 55 to $70^{\circ}$ $\mathrm{C}$ (the optimum temperature is 55 to $60^{\circ} \mathrm{C}$ ). Heat pumps differ, primarily, by the source of low-potential energy. As a medium for extraction of low-potential thermal energy, the following substances can be used: soil (ground heat pumps); water, including sewage and geothermal sources (heat pumps water / water or water / air); and air.

In terms of the city of Baikalsk, ground-based heat pumps will require significant (approximately 60,000 rubles / $\mathrm{kW}$ ) capital costs, which is associated with the need to drill a large number of wells up to 30 meters deep. Until now, there is no reliable information on how many wells will be required to provide heat to a particular building, taking into account the need to restore the reserves of thermal energy of the ground in the inter-heating period. There are no geothermal sources in the zone of the Baikalsk municipality. The idea of using water from Lake Baikal with the initial temperature in the winter period of $3^{\circ} \mathrm{C}$ and the final temperature at the exit from the heat pump of $1{ }^{\circ} \mathrm{C}$ in the scales of the city's heat supply system is not acceptable.

The potential of heat energy of sewage at the outlet from the treatment facilities in Baikalsk can be estimated at about $3.2 \mathrm{Gcal} / \mathrm{h}$. The use of this potential to cover the needs of treatment facilities and partial coverage of the load on hot water supply to the industrial 
site should be considered as a promising one. The main technical and economic indicators of the heat pump in wastewater are presented below.

Due to the thermal energy accumulated by Lake Baikal, under the influence of winds directed from the lake, winter temperatures in the city of Baikalsk and throughout the southern and south-eastern Baikal region rarely fall below $-15-20^{\circ} \mathrm{C}$. Taking into account such a microclimate, it seems promising to use air heat pumps in combination with peak electric boilers. At such outdoor air temperatures, air-fueled heat pumps provide a conversion factor (the ratio of the received thermal energy to the consumed electric energy) equal to 4.

In the Table 3, calculation of the cost price of thermal energy received on air heat pump of Mitsubishi is resulted at an electric energy cost 3.4 rubles / $\mathrm{kWh}$. It is assumed that the air heat pump takes about $70 \%$ of the load, and the remaining $30 \%$ are covered by the peak electric boilers. The average weighted cost price of thermal energy in this case will be 2,615 rubles / $\mathrm{kWh}$. At a tariff for the electric energy of 2 rubles / $\mathrm{kWh}$, the average cost price of thermal energy will be 1878 rubles per Gcal. By the criterion of the cost price, the electric power sources are not competitive in comparison with other heat sources, except for the options with heat pump installations.

Table 3. The cost price for the production of the heat energy by the house air heat pumps, including connection fees.

\begin{tabular}{|l|c|c|}
\hline \multicolumn{1}{|c|}{ Indicator } & Value & $\begin{array}{c}\text { Unit of } \\
\text { measurement }\end{array}$ \\
\hline annual heat output & 84250 & thousand Gcal \\
\hline Total with efficiency factor 99\% & 85101 & Gcal \\
\hline Costs: & & \\
\hline$-\quad$ Electric energy & 21062,46 & MWh \\
\hline- EE costs, with a tariff of 3.4 thousand rubles / MWh & 71612,40 & thousand rubles \\
\hline Depreciation & 52000 & thousand rubles \\
\hline Other & 23184 & thousand rubles \\
\hline Total & 146796 & thousand rubles \\
\hline The cost of heat & 1,742 & rubles / Gcal \\
\hline
\end{tabular}

Advantages of the options with the use of the air heat pumps:

- Reliability of the heat source;

- Absence of environmental damage;

- Saving when using secondary thermal energy of discharges;

- Can be considered as additional sources of energy in certain areas of the city in order to optimize the heat supply system.

Disadvantages:

- High cost of capital investments;

- $\quad$ Lack of sufficient volume of secondary energy resources;

- Insufficient reliability and high costs for the construction of pipelines when using the water of Lake Baikal as a source of thermal energy;

- $\quad$ The need to provide electricity.

Heat pump systems can be considered as additional sources of energy in certain areas of the city in order to optimize the heat supply system, including the treatment facilities. The potential of the secondary heat energy of the sewage is about $3.5 \mathrm{Gcal} / \mathrm{h}$.

The air heat pumps can be considered preferable for individual houses, in which tariffs are lower. At a tariff for electric energy of 2 rubles $/ \mathrm{kWh}$, the average cost price of the thermal energy will be 1878 rubles per Gcal.

Solar heating systems. The use of solar energy is the most environmentally friendly technology. The use of solar energy for the needs of heat supply using solar collectors (SC) 
is considered here $[6,8,9]$. The solar collectors are a set of elements that absorb and convert solar radiation into the thermal energy, which is transferred to the heat carrier. The performance of the solar collector is a function of the intensity of solar radiation falling to the receiving area, the effective area of the receiving area, and the efficiency of the receiver.

The most common solar collectors have an effective area of $2-2.5 \mathrm{~m}^{2}$ and efficiency of $0.6 \%-0.75 \%$. Relatively cheap Chinese collectors on the basis of vacuum tubes (cost from 40 to 45 thousand rubles for one collector of $2.2 \mathrm{~m}^{2}$ ) currently prevail on the market of solar collectors. Similar collectors from Germany are offered at a price of 60 thousand rubles for one collector. Before the crisis of 2008, which caused a sharp rise in the price of dollars, Chinese collectors could be purchased at a price of 8,000 rubles, and this constrained the possibility of own production. Recently, the collectors of the Russian manufacture, in particular, solar collectors "YaSolar" of the "New pole" Company at the price from 20 thousand rubles have appeared on the market.

The Table 4 shows a typical configuration of the solar heat supply system - a water heating system based on the solar collectors "Yasolar" with copper selective absorber TiNOX. Such an installation is designed to heat the coolant (water, antifreeze, etc.) by direct effective absorption of solar radiation. The main element of the system, the solar collector, is designed in the form of modules. The modules allow easily increasing the volume of heated water by connecting them to the systems, and they can easily be integrated into traditional water heating systems. The system can be either a basic or a parallel alternative energy source.

Table 4. Composition of the equipment of the solar heat supply system.

\begin{tabular}{|c|l|c|c|}
\hline No. & \multicolumn{1}{|c|}{ Name of the item } & Quantity & $\begin{array}{c}\text { Unit of } \\
\text { measurement }\end{array}$ \\
\hline 1 & $\begin{array}{l}\text { Solar collector "YaSolar", 2 } \mathrm{m}^{2} \text {, copper absorber TiNOX. } \\
\text { antiglare glass }\end{array}$ & 15 & $\mathrm{pcs}$ \\
\hline 2 & Boiler SOLAR 750 Duo, enamel & 1 & $\mathrm{pcs}$ \\
\hline 3 & Boiler SOLAR 500, enamel & 1 & $\mathrm{pcs}$ \\
\hline 4 & Buffer capacity AT MONO 1000 & 1 & $\mathrm{pcs}$ \\
\hline 5 & Pumping circulation station & 1 & $\mathrm{pcs}$ \\
\hline 6 & $\begin{array}{l}\text { 8-channel digital controller with sensors in the sleeve }(1 \mathrm{pc} \text { of } \\
\left.\text { high-temperature up to +250 }{ }^{\circ} \mathrm{C}, 7 \text { pcs up to }+180^{\circ} \mathrm{C}\right) .\end{array}$ & 1 & $\mathrm{pcs}$ \\
\hline 7 & Expansion tank Zllmet 35 1(Italy) & 1 & $\mathrm{pcs}$ \\
\hline 8 & $\begin{array}{l}\text { Breather +180"C (complete) with collet connection 22 mm, } \\
\text { with a 3/8" tap, sensor sleeve }\end{array}$ & 3 & $\mathrm{pcs}$ \\
\hline 9 & Breather +180"C & & \\
\hline
\end{tabular}

Daily and seasonal fluctuations are the specific feature of solar energy. The Figure 1 presents the schedule of solar energy supply to the receiving area by months. The greatest income occurs in the summer months, when the demand for thermal energy falls. At the same time, due to the high cost of solar systems, it is necessary to provide the maximum utilization factor. Therefore, solar collectors of any design should be considered only as a source of thermal energy to partially cover the load of hot water supply and heating.

Heat transfer from the solar collector "YaSolar" is executed by the means of a heat exchanger in a buffer tank, or a heat exchanger in a boiler for heating hot water. Antifreeze is used as the coolant of the heating system and for filling the heat accumulator. The electric heater PETN, controlled by a digital controller, can be an auxiliary heat source in any season and in any operating mode. In winter, the main source of heat can be a traditional boiler or heat pump.

To ensure trouble-free operation of the solar heat supply system, it is necessary to ensure power supply to the digital controller and the circulating pump of the solar system. This can be provided by a backup power system with an uninterruptible power supply and a battery or a solar power system (optional). 


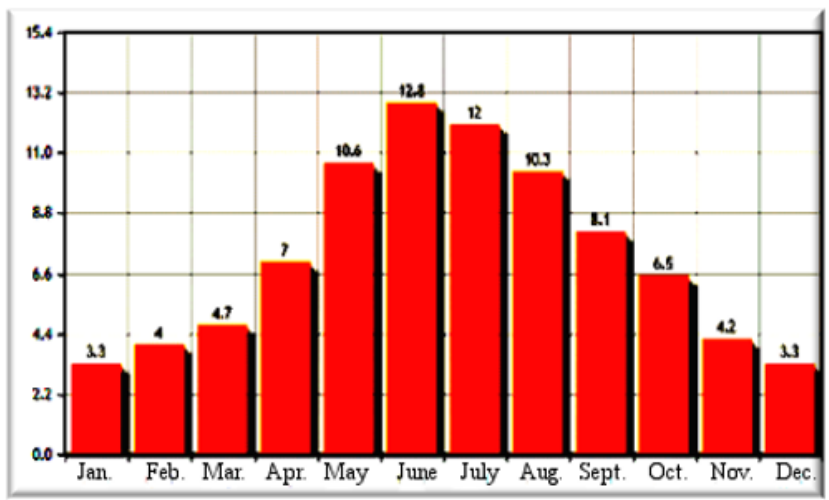

Fig. 1. The average daily amount of solar radiation.

The approximate cost of such a system with a solar power supply unit is 600 thousand rubles. The total cost of the system is 603 thousand rubles. The Table 5 demonstrates the calculation of the thermal energy production potential by such an installation with 15 collectors with a total area of $30 \mathrm{~m}^{2}$. At latitude of 52 degrees, the maximum power of solar radiation falling on the receiving surface at a right angle at noon in June is about $0.98 \mathrm{~kW}$. The calculation takes into account the efficiency, the duration of insolation and the proportion of cloudy days that reduce radiation.

The annual capacity of the plant will be approximately $32 \mathrm{Gcal} /$ year. At a cost of thermal energy of 1500 rubles / Gcal, the system provides thermal energy for the amount of 47.9 thousand rubles per year. The payback period is 12.6 years. The average annual capacity of the installation is $7.4 \mathrm{~kW}$. The specific cost of $1 \mathrm{~kW}$ is 81.5 thousand rubles / $\mathrm{kW}$ of installed capacity. In the horizon of calculation of 25 years, the depreciation component of the cost of a solar installation is 503 rubles / Gcal. If we assume that for the maintenance of 10 units, the cost will be 12 thousand rubles per year, then the operating component of the cost price will be 25 rubles / Gcal. Total cost of 1 Gcal will be equal to 528 rubles / Gcal.

Advantages of solar heat supply systems:

- No environmental damage.

- $\quad$ Cost-effective in maximizing utilization.

- Minimal operating costs.

Disadvantages:

- Significant daily and seasonal fluctuation. The need for thermal energy storage or regulatory tools. This disadvantage can be eliminated by using solar systems as a part of a common heat supply system to partially cover the loads that ensures full utilization of their potential. Another option is the use of solar systems for the objects, in which the peak of thermal energy consumption coincides with the peak performance of solar systems (recreational facilities).

- Insufficient reliability. Dependence on weather factors. The need to reserve other sources of thermal energy.

High cost of capital investments. Specific cost of solar collectors.

Taking into account the above-mentioned properties of solar collectors, the following conclusions are drawn:

Solar heat supply systems can be considered as additional sources of thermal energy, which increase the environmental compatibility and economy of the heat supply system as a whole.

Operating costs for the maintenance of solar heat supply systems are minimal and after complete depreciation they can be considered as practically free energy sources. 
Solar heating systems need to be introduced, as in the long run they provide a significant reduction in the cost of heat supply.

Table 5. Potential for the production of thermal energy by solar collectors.

\begin{tabular}{|c|c|c|c|c|c|c|c|c|c|c|c|c|c|}
\hline \multirow{2}{*}{ Indicator } & \multicolumn{12}{|c|}{ Month } & \multirow{2}{*}{$\mathbf{Y}$} \\
\hline & 01 & 02 & 03 & 04 & 05 & 06 & 07 & 08 & 09 & 10 & 11 & 12 & \\
\hline $\begin{array}{l}\text { Monthly } \\
\text { heat } \\
\text { supply per } \\
\mathrm{m}^{2}, \mathrm{MJ} / \\
\left(\mathrm{m}^{2}\right. \\
\text { month) }\end{array}$ & 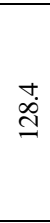 & $\begin{array}{l}\stackrel{\infty}{ } \\
\end{array}$ & शे & $\begin{array}{l}\text { t. } \\
\text { రें }\end{array}$ & \begin{tabular}{l}
$n$ \\
\multirow{n}{*}{} \\
$n$
\end{tabular} & $\begin{array}{l}\overrightarrow{\hat{\sigma}} \\
\bar{\delta}\end{array}$ & 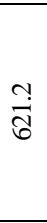 & $\stackrel{\substack{+\\
}}{ }$ & $\vec{g}$ & $\frac{\stackrel{N}{m}}{m}$ & 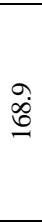 & $\begin{array}{l}\stackrel{0}{\dot{\Xi}} \\
\end{array}$ & 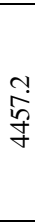 \\
\hline $\begin{array}{c}\text { Same in } \\
\text { Gcal / } \mathrm{m}^{2} \\
\text { month }\end{array}$ & $\vec{\delta}$ & ஜ̊. & :̊̊. & $\begin{array}{l}\stackrel{0}{=} \\
\stackrel{0}{0}\end{array}$ & $\frac{\pi}{0}$ & $\stackrel{n}{\mathscr{n}}$ & $\frac{\infty}{\stackrel{\infty}{0}}$ & 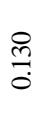 & $\frac{8}{0}$ & $\stackrel{+}{\stackrel{5}{0}}$ & 웅 & 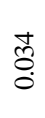 & 8 \\
\hline $\begin{array}{c}\text { Heat } \\
\text { energy } \\
\text { input at } 15 \\
\text { collectors } \\
30 \mathrm{~m}^{2} \text {, } \\
\text { Gcal/ } \\
\text { month }\end{array}$ & $\delta$ & $\stackrel{\text { ọ }}{.}$ & $\vec{i}$ & m. & $\hat{\mathrm{m}}$ & $\stackrel{n}{r}$ & $\stackrel{f}{f}$ & $\underset{m}{\text { r }}$ & $\frac{\infty}{\dot{m}}$ & તָ & ઼ָ & $\underset{\sigma}{\sigma}$ & $\stackrel{\$}{\text { m. }}$ \\
\hline
\end{tabular}

\section{Conclusions}

Taking into account the full complex of system factors, coal boiler plants in the near future cease to be the cheapest heat sources for many small and medium-sized remote settlements of the Baikal region. It is advisable to optimize the heat supply schemes. Herewith, in many cases the introduction of boilers operating on environmentally friendly biofuels, including those grown on the plantations, is promising [10-11]. In the future, it is advisable to consider the prospects of using liquefied natural and liquefied hydrocarboncontaining gas in the work of mini-thermal power plants as sources of energy supply for small and medium-sized settlements of Eastern Siberia. These measures can provide for a significant improvement of the environmental situation in the Baikal region. In addition, as a way to optimize the structure of the heat supply system, it is advisable to use heat pump systems and solar heat supply systems.

\section{References}

1. A. Perov, Why reform of heat supply? (https: //eadaily.com/en/news/2016/06/18/reforma-teplosnabzheniya-v-rossii-esli-nichego-nedelat-tarify-tozhe-budut-rasti, 2016)

2. Government of Russia, Order of the Government of the Russian Federation Implementation of the target model of the market of thermal energy, 1949-r (Moscow, 2014)

3. V. V. Khan, N. P. Dekanova, T. A. Romanova, Izvestiya Vuzov. Investments. Building. Real Estate, 4, 146 (2016) 
4. Ministry of Natural Resources of Russia, The Order of the Ministry of Natural Resources of Russia 63 on the approval of the maximum permissible impacts on the unique ecological system of the Lake of Baikal and the list of harmful substances, including substances belonging to the categories of especially dangerous, highly dangerous, moderately dangerous for the unique ecological system of the Lake of Baikal (Moscow, 2010)

5. Federal Law on the Protection of the Lake of Baikal, 94-FZ (Moscow, 1999)

6. V. Khan, N. P. Dekanova, P. V. Khan, International Conference on Construction, Architecture and Technosphere Safety, V. 262, 1, (2017)

7. V. A. Butuzov, International Scientific Journal For Alternative Energy And Ecology, 7, 48 (2009)

8. I. S. Gnatyuk, V. A. Butuzov, Innovations in Agriculture, 5(20), 130-135 (2016)

9. Heating systems of individual houses with the help of heat pumps ECODAN (https: //mitsubishi-kostov.ru/d/427696/d/ecodan_mitsubishielectric_2016_1.pdf, 2016)

10. E. V. Gubii, V. I. Zorkaltsev, Proceedings of the All-Russian Scientific and Practical Conference with International Participation "Increasing the Efficiency of Energy Production and Use in Siberia", 100-105 (2017)

11. E. V. Gubii, V. I. Zorkaltsev, Analysis, modeling, management, development of economic systems: collection of scientific papers, 102-105 (2014)

12. A. V. Bogoviz, S. V. Lobova, Y. V. Ragulina, A. N. Alekseev, International Journal of Energy Economics and Policy, 7(5), 93-101 (2017)

13. V. V. Khan, N. P. Dekanova, T. A. Romanova, S. A. Sharaeva, Izvestiya Vuzov. Investments. Building. Real Estate, 7(1), 101-113 (2017) 